\title{
Az inulin szerepe és jelentősége a gazdasági haszonállatok takarmányozásában
}

\section{Tóth Szandra ${ }^{*}$, Kovács Melinda1,2, Fébel Hedvig³}

${ }^{1}$ Kaposvári Egyetem, 7400 Kaposvár, Guba S. 40.

${ }^{2}$ MTA-KE Mikotoxinok az Élelmiszerláncban Kutatócsoport, 7400 Kaposvár, Guba S. 40.

${ }^{3}$ NAIK Állattenyésztési, Takarmányozási és Húsipari Kutatóintézet, 2053 Herceghalom, Gesztenyés 1.

ABSTRACT - The role and significance of inulin in the feeding of farm animals

Author: Szandra Tóth ${ }^{1}$, Melinda Kovács ${ }^{1,2}$, Hedvig Fébel ${ }^{3}$

Affiliation: ${ }^{1}$ Kaposvár Universty; ${ }^{2 M T A-K E}$ Mycotoxins in the Food Chain Research Group,7400 Kaposvár, Guba S. str. 40., Hungary; NAIK Research Institute for Animal Breeding, Nutrition and Meat Science, 2053 Herceghalom, Gesztenyés str. 1.

Restrictions on the use of antibiotics in Regulation (EC) No 1831/2003 of the European Parliament and of the Council have increased the need for preventive measures in animal nutrition. The positive dietary effects of inulin have been documented since the early 1900s. This compound is a carbohydrate which has prebiotics effect. On its role in animal nutrition, about the performance-enhancing properties, today's literature gives different results. The aim of our summary work is to acquaint the structure of inulin, its effect on the body and its practical use with out the need for completeness. The mostly effects of inulin is the ability to change the composition of the hind gut microbiome. Increased microbial fermentation increases the volatile fatty acid concentration and decreases the intestinal $\mathrm{pH}$, which inhibits the growth of pathogens in the digestive tract. It affects the intestinal morphology, the body's immune system, and its clinical chemical parameters. The measurable changes depend on the structure of inulin, the species, age, health and nutritional status of the animal. Observations in piglets have shown a reduction in feed efficiency and nitrogen metabolism at certain doses. In the light of scientific results, the practical role of inulin as a dietary supplement to improve health is well established, but the precise study of upper limits and the structure of efficiently functioning fructan is still a challenge for science.

Keywords: prebiotics, inulin, intestinal microflora, immunology

\section{BEVEZETÉS}

Az állattenyésztés elsődleges célja az egészséges élelmiszer eloállítás az emberiség számára úgy, hogy figyelembe vegye az állatok jóllétét és a környezet védelmét (Gaggia és mtsai, 2010). Az1831/2003/EK európai parlamenti és tanácsi rendeletben a Tudományos Operatív Bizottság betiltotta az antibiotikumokhozamfokozó céllal történő felhasználását a takarmányokban. A döntés utánintenzív kutatás indult az antibiotikum kiváltására szolgáló, egészségmegőrző, betegség megelőző hatással bíró készítményekkel kapcsolatbanaz élelmiszer- és a takarmányiparban egyaránt. A rendelet óriási 
nyomást gyakorolt az állattartó gazdaságokra, és egyik fő következménye a terápiás antibiotikumok használatának növekedése lett (Casewell és mtsai, 2013). Ez a trend arra ösztönözte a kutatókat, hogy új, biztonságosabb alternatívát keressenek az állatok egészségének megóvása érdekében (Verdonk és mtsai,2005; Verstegen és Williams, 2002). A bél mikroflórája és a szervezet egészsége közti összefüggés már Ilja Mecsnyikov 19. századi kutatómunkájából ismert és azóta is számos értekezés jelent meg,amely segít jobban megismerni ezt a szervezeten belüli összetett rendszert. A probiotikum szót mai értelmében vett kifejezésként először R. B. Parker használta (Parker, 1974). A legújabb kutatási eredmények szerint, a bélnyálkahártya felszínén élő bélflóra az alábbi élettani funkciókban nélkülözhetetlen: táplálék emésztése,a táplálóanyagok felszívódása, patogénekkel szembeni küzdelem, méregtelenítés, immunrendszer működése, enzimek, vitaminok és neurotranszmitterek termelése, endokrin rendszerre kifejtett hatás, gyulladásos folyamatok mérséklése (Loveren és mtsai, 2012; Hill és mtsai, 2014; Perlmutter, 2017). Habár a bél mikrobióta komplex rendszer és a gazdaszervezet számára hasznos tulajdonsággal bíró baktériumok szabályozása nem tisztázott, a Lactobacillus és Bifidobacterium törzsek képesek védelmet nyújtani az emésztőszervi fertőzésekkel szemben (Gaggia és mtsai, 2010). A prebiotikumok olyan nem emészthető adalékanyagok, amelyek jótékonyan befolyásolják a gazdaszervezet egészségét azáltal, hogy szelektíven stimulálják bizonyos vastagbélben található baktériumok szaporodását és aktivitását (Gibson és Roberfroid, 1995). Ott szolgáltatnak energiát a baktériumok számára, ahol a glükóz, mint energiaforrás már nincs jelen (Adebola és mtsai, 2014). A legismertebb prebiotikumok a nem keményítő eredetű növényi szénhidrátok és oligoszacharidok, amelyek különféle molekuláris struktúrában használatosak atáplálkozásban, illetve az állatok takarmányozásában. Ennek a legtöbbet kutatott csoportjai a fruktooligoszacharidok (FOS, oligofruktózés inulin), galaktooligoszacharidok (GOS), transzgalakto-oligoszacharidok (TOS) és a laktulóz (Gaggia és mtsai,2010).

Jelen cikk segít megismerni az inulin, mint prebiotikus tulajdonsággal rendelkező fruktán hatásmechanizmusát és szerepét a humán táplálkozásban és a gazdasági állatok takarmányozásában.

\section{AZ INULIN ELŐFORDULÁSA, SZERKEZETI FELÉPÍTÉSE}

Az inulin különböző lánchosszúságú, $(2,1)$ lineáris kötésű fruktánok gyűjtőneve, amely több mint 36000 növényfajban megtalálhatóúgy, mint spárga, póréhagyma, vöröshagyma, banán, búza,fokhagyma, cikória és articsóka 
(Metzler-Zebeli és mtsai, 2017). A vegyületnek a növényekben energiatároló funkciója van és általában a gyökérben vagy a rizómákban halmozódik fel. Azok a növények, amelyek inulint raktároznak, általában nem, vagy kisebb arányban tartalmaznak keményítőt. Nevét az örménygyökér (Inulahelenium) latin nemzetségneve után kapta. Az inulin típusú fruktánok $\beta(1 \leftarrow 2)$ kötéssel kapcsolódó fruktozil és fruktóz monomerekből álló lineáris vegyületek (Gibson és Roberfroid, 2008). A kereskedelmi forgalomban kapható inulint vagy a cikória növény gyökeréből nyerik, vagy szacharózból szintetikus úton állítják elő (Niness, 1999). A cikória (Cichoriumintybus) gyökere 15-20\%inulint és 5-10\% egyéb oligofruktózt tartalmaz. A fruktánok jellemzésére 2 mértékegység szolgál. Egyik a DP (Degree of Polymerization) ami a vegyületben szereplő fruktán monomerek hosszúságának tartományát mutatja meg. A DPav (Average Degree of Polymerization) pedig azt, hogy a fruktán átlagosan milyen hosszúságú monomereket tartalmaz (Gibson és Roberfroid, 2008).A lánchosszúság alapján megkülönböztetünk relatív rövid (2-4), közepes (5-10) és relatív nagy (11-60) lánchosszúságú fruktánokat. A nomenklatúra nem teljesen egyezik a tudományban. Vogt és mtsai. (2015) az inulin típusú vegyületek nevezéktanának változásáról így nyilatkoztak: eleinte a szacharózból származtatott DP 3-5 hosszúságú anyagot nevezték FOS-nak (Fruktooligoszaccharid), majd a DP 310 tartományba eső inulin vegyületeket OF-nek, azaz oligofruktóznak. Később ezeket egymás szinonímájaként használták és esetleg a „rövid/hosszú láncú” előtaggal pontosították a leírást. Az inulin elnevezést általában a DP>10 hoszszúságú vegyületekre használják, holott a nevezéktan szerint minden $\beta(2-1)$ típusú fruktán, lánchosszúságtól függetlenül, ebbe a csoportba tartozik. $\mathrm{DP}<10$ értékkel rendelkező fruktánok jól oldódnak, gyorsan fermentálhatóak és szelektív interakcióra képesek a bél mikroflórával (Van Loo, 2007). Az ennél hoszszabb láncú fruktánok lassabban, a későbbi bélszakaszokban fermentálódnak, ami így kisebb mértékben hat a bélflóra összetételére. Ez a tulajdonság nagyon fontos meghatározója lehet egy kísérletben kapott eredmény értékelésének, ugyanis már McKellar és mtsai. (1993) rávilágítottak arra, hogy a Lactobacillus többnyire a bélrendszer proximális részén, míg a Bifidobaktérium a vastagbélben kolonizálódnak eredményesebben. A cikória-kivonatból készült inulin 3050\%-ban DP<10 hosszúságú fruktánokat tartalmaz. A fennmaradó rész a hoszszabb láncú alkotóké. Belval 1927-ben már leírta az inulin kinyerésének metodikáját. Az eljárás hasonlatos a cukorgyártás folyamatához. A cikóriát a cukorrépához hasonlóan szeletelik, majd mossák. A mosást követően az inulintmelegvizes diffúziós eljárással nyerik ki. Ennek eredményeként DP 2-60 lánchosszúságú oligofruktóz nyerhető (DPav =10-12). A nagy tisztaságú inulin 
gyártásához a rövid láncú molekulákat eltávolítják, így DPav érték 25-re emelkedik, amiben a monomerek hossza 11 és 60 között változik (DP=11-60) (Niness, 1999). A hosszú láncnak köszönhetően nehezebben oldódik, mint az egyéb oligofruktózok. Tejjel vagy vízzel mikrokristályokat alkot, amely előnyös az élelmiszeripar számára, bizonyos termékek (töltelékek, tejtermékek, dresszingek) kedvező állagának eléréséhez. Niness (1999) értekezésében beszámol az inulin élelmiszeriparban betöltött szerepéről, mely szerint a hozzáadott rosttartalom növeléséhez széles körben használt anyag, ugyanis más rosttokkal ellentétben nincs mellékíze, nem befolyásolja a viszkozitást.

\section{AZ INULIN SZERVEZETRE GYAKOROLT HATÁSA}

\section{Az inulin hatásmechanizmusa a bél mikrobiom szabályozásában}

Az elmúlt évtizedben nőtt az olyan étrendi összetevők iránti igény, mint a preés probiotikumok, amelyek képesek a bélmikroflóra stabilitását javítani. A prebiotikumok emészthetetlen étrendi alkotók, amelyek tápanyagul szolgálnak a probiotikumok növekedéséhez a szervezetben (Huebner és mtsai, 2007). $\mathrm{Az}$ emlősökben a fő táplálékforrástól függően változik a bélben található mikrobiom összetétele és mennyisége is. A növényevők mikrobiomjának száma jelentősebb, összetétele változatosabb, míg a ragadozóké kevésbé öszszetett és jelentős (Gaggia és mtsai, 2010). Ezen felül természetesen befolyásoló tényező az életkor és az általános egészségügyi állapot, környezeti patogén terhelés mértéke is. Mivel ez a mikrobiális populáció nagyon összetett és akár több száz fajt tartalmazhat, általában két csoportra osztja a szakirodalom, a pontos meghatározás helyett. Elkülöníthetőek az emésztést, gazdaszervezet egészségét kedvezően befolyásoló alkotók és a patogének. Előbbi esetében 2 fő nemzetségre fókuszálnak a kutatások, a Lactobacillusokra és a Bifidobacteriumokra. A Lactobacillus nemzetség széles és heterogén taxonómiai egység, amely több száz különböző tejsavtermelő baktériumfajból áll (Gaggia és mtsai, 2010). A Bifidobacterium nagyszámú előfordulása a gazdaszervezet jó egészségére utal. Segítenek a bélrendszer megfelelő mikrobióta egyensúlyának fenntartásában azzal, hogy csökkentik a kórokozók megtelepedésének esélyeit (Gaggia és mtsai, 2010). Ahogyan azt Halas és mtsai. (2009) is megfogalmazták, az inulin hatására bekövetkező bakteriális szaporodás gátolja az enterotoxikus Escherichia coli felszaporodását, és így csökkenti a hasmenés kockázatát. Niness (1999) szerint az inulin legismertebb táplálóanyagokra vonatkozó hatása az a stimuláns aktivitás, amit a bélben a Bifidobacteriumra fejt ki. Az 1990-es években számtalan humánkísérlet bizo- 
nyította 5-20 g/nap inulin-kiegészítés jótékony hatását a Bifidobacterium szaporodására (Niness, 1999). Az inulin típusú fruktánok ellenállnak a hidrolizáló enzimeknek a vékonybélben és könnyen fermentálhatóak a szacharolitikus baktériumok számára (Metzler-Zebeli és mtsai, 2017). McKellar és mtsai. 1993ban in vitro vizsgálták különféle Bifidobacterium törzsek szaporodási képességét inulinnal $(\mathrm{DP} \geq 15)$ dúsított közegben és úgy találták, hogy a $B$. thermophilum $B$. minimum és $B$. cuniculi törzsek növekedésének kedvezett a fruktán-kiegészítés. Adebola és mtsai. (2014) szintén in vitro környezetben mérték az inulin, mint prebiotikum hatását Lactobacillus törzsekre. A $L$. acidophilus NCFM számát kis mértékben növelte 0,5-2,5\%-os inulin-kiegészítés. Huebner és mtsai. (2017) in vitro vizsgálatai során az inulin táptalaj nagymértékben $(\mathrm{P}<0,05)$ segítette a Lactobacillus paracasei szaporodását, míg csökkentette az E. coli-ét, azonban a Bifidobacterium bifidum esetében az inulin gyenge táptalajnak bizonyult. Verdonk és Leeuwen (2004) ileumkanüllel ellátott borjakban végzett vizsgálatban követték nyomon az inulin útját az emésztőtraktusban. Méréseik szerint az inulin típusú fruktánok 70\%-a emésztetlenül kerül a vastagbélbe, azonban a bélsár nem tartalmazza ezeket az anyagokat. Ez a megfigyelés egyetértésben van Bosscher és mtsai. (2006) állításával, miszerint az emlősök nem emésztik az inulint és oligofruktózt, így érintetlenül érik el a vastagbelet, ahol a mikroflóra, különösen az endogén tejsavtermelő baktériumok, a Bifidobacterium és a Lactobacillus fermentáljákazt. Ezzel szemben Branner és mtsai. (2004) valamint Böhmer és mtsai. (2005) malacokon végzett vizsgálataik során úgy tapasztalták, hogy a béltartalom a jejunumban és az ileumban ugyan még tartalmaz inulint, azonban a vakbél- és vastagbéltartalom már nem. Bár a fermentációs tevékenység pontos helyében nem, de abban egyetértenek a kutatások, hogy az inulin hatással van a vastagbél és bélsár baktériumtartalmára. Van Loo és mtsai. (2006) fisztulázott lovakon figyelték meg 2\% inulin-kiegészítés vakbél-fermentációt stimuláló hatását. A szelektív fermentáció és ezzel együtt a bifidogenikus hatás a Bifidobacterium bétafruktozidáz enzimének köszönhetően jön létre (Król, 2011). Ez az enzim bontja le az inulinban és az oligofruktózban a $\beta(2-1)$ glikozid kötéseket. ABifidobacterium fermentációs termékei a rövid szénláncú illózsírsavak (short chain fatty acids, SCFA), amelyek hatására csökken a béltartalom pH-ja, ami így gátolja a patogén baktériumok szaporodását (Van Loo 2007; Król 2011; Adebola és mtsai, 2014). Ezt alátámasztja SooBo 2005-ben sertéseken végzett tanulmánya is, ahol megállapította, hogy a fokozott bakteriális tevékenységnek köszönhetően nő az illózsírsavakmennyisége. Adebola és mtsai. (2014) szerint az így fellépő pH csökkenés a kulcsmechanizmus a patogének visszaszorításában, azonban meg kell említeni azt is, hogy a prebiotikumok bizonyos 
koncentráció fölött képesek 5 alá csökkenteni a vastagbéltartalom pH-ját, ami már gátolja a probiotikumok szaporodását. Ez magyarázatot adhat MetzlerZebeli és mtsai. (2017) állítására, miszerint az inulin-kiegészítés nagyobb adagja csökkentette a Bifidobacterium és az Enterobacterium számát a vastagbélben. Adebola és mtsai. (2014) szerint egyes prebiotikumok képesek a Lactobacillust megvédeni az epesavak károsító hatásaitól, ezzel is kedvezve azok szaporodásának. Ez szintén fontos megállapítás a tekintetben, hogy megértsük mennyire összetett folyamat a bél mikrobiom összetételének szabályozása.

Csekély számú kutatás foglalkozik felnőtt kérődzők takarmányának inulinkiegészítésével. Ennek oka lehet, hogy a bendőben élő hatalmas mennyiségű és fajgazdagságú baktériumtömeg teljes mértékben fermentálja a kiegészítésként adott inulint és egyéb fruktánokat. A prebiotikumoknak így nincs esélyük elérni a tápcsatorna hátsó szakaszaiba ahol pozitív hatásukat valóban kifejthetnék (van Loo, 2007). Hall és Weimer (2016)in vitro vizsgálata azt igazolta, hogy az inulin a bendőben más fruktánoknál lassabban bomlik le,a glükózhoz képest 20\%-kal javítja a baktériumok N-felhasználását, növeli a bendőfolyadék ecetsavtartalmát és a biomassza tömegét. A mikrobiom zömét a Bacteroides és Firmicutes törzsekhez tartozó fajok adják, azok közül is legföképpen a Clostridiumok és Lactobacillusok vannak jelen. Samanta és mtsai. (2013) megfigyelték, hogy juhok és holstein tehenek bendőjében prebiotikuskiegészítés hatására csökkent az ammónia-termelő baktériumok száma és ezáltalkisebb lett az ammónianitrogén koncentrációja a bendőfolyadékban.

\section{Az immunmoduláció és az inulin-kiegészítés összefüggése}

Król (2011) szerint a prebiotikumok potenciális gyakorlati lehetősége a betegségekkel szembeni nem specifikus immunválaszban rejlik. Az immunológiai vizsgálatok laborállatokon a legcélravezetőbbek, hiszen sokkal kontrolláltabb környezetben vizsgálhatóak, mint a gazdasági haszonállatok, így ebben a témában fóleg rágcsálókon és kutyákon tapasztalt változásokat írnak le (Lomax és Calder, 2009). A kétezres években számos kutatás foglalkozott az inulin típusú fruktánok közvetlen immunstimuláló hatásával (Vogtés mtsai, 2015). Az immunrendszerrel összefüggő hatás sok tényezőt foglal magában, az eredmények két fő csoportra oszthatók, a GALT-ban (gut associated limfoid tissue) és a szisztémás immunrendszerben bekövetkezett változásokra (Lomax és Calder, 2009). A GALT a bélnyálkahártyával társult nyirokrendszer, amely a bél szöveteiben a hám és nyálkaréteg alatt helyezkedik el. Az itt található M sejtek állítják elő és juttatják el az antigéneket a bél lumentől a peyerplakkokhoz ahol 
az antigén a limfocitákkal találkozik és aktiválódik. Ezt követően ezek a limfociták a nyirokrendszeren keresztül eljutnak az egész szervezetbe és a bélcsatorna más részeibe is. Vogt és mtsai. (2015) szerint, az inulin direkt hatással van a fent említett élettani folyamatokra, ami így befolyásolja a gazdaszervezet egészségét. Itt kell megemlíteni, az inulin és a sejtmembrán lipidjei között fellépő kapcsolatot is, amely dinamikusabbá teszi a membránt és megkönnyíti a receptorok kapcsolódását és a jelátvitelt (Vogtés mtsai, 2015). Ez összefüggésben állhat Masanetz és mtsai. (2011) megállapításával, miszerint nő a vastagbél PECAM1 (Platelet Endothel Cell Adhesion Molecule-1 = vérlemezkeendotél sejtadhéziós molekula) előfordulása. Ez a molekula az immunglobulin család tagja, amelynek segítségével a fehérvérsejt átjut az intercelluláris térbe. Az előző fejezetben tárgyalt SCFA és egyéb fermentációs termék koncentrációja inulin hatására emelkedik, amely gyorsan felszívódva közvetett hatást gyakorol az immunsejtekre azáltal, hogy aktivált G proteinekhez kapcsolódnak (Vogt és mtsai, 2015; Huang és mtsai, 2015). A veleszületett immunrendszert érintő vizsgálatok során Lomax és Calder (2009) azt tapasztalták, hogy a $\beta$ 2-1 fruktánok kedvezően hatnak a makrofágok számára és funkcionalitására. Rágcsálóknál megfigyelték, hogy inulin-kiegészítés esetén nőtt a peritoneális makrofágok fagocitózis aktivitása, ahogy a nyirokcsomók antigén szállító sejtjeik hisztokompatibilitási komplex (MHC) II molekula expressziója is, míg a „naturalkiller” sejtek citotoxicitása nem változott a kutyákkal és patkányokkal végzett tanulmányok szerint (Lomax és Calder, 2009). A kutatások zöme beszámolt a vérszérum és a bélsár IgA valamint IL-10 és IFN- $\gamma$ koncentrációjának növekedéséről (Vogt és mtsai, 2015).Huang és mtsai. (2015) brojlercsirkék élettani paramétereit vizsgálták az első 3 élethétben. Az általuk mért értékek szerint a vakbél IgA, és a jejunumm RNS szintje fokozódott, miközben csökkent az interleukin-6 és interferon-y. Ezek az eredmények a kutatók szerint azt jelzik, hogy a tápok 5-10 g/kg inulinnal történő kiegészítése jótékony hatással lehet a brojlercsirke intesztinális immunfunkciójának fokozására fiatal korban. Ezzel szemben Masanetz és mtsai. (2011) szerint a prebiotikum hatására nő a gyulladáscsökkentő IL10 molekulák előfordulása, ami a patogének számának visszaszorításával együtt az immunaktivitás csökkenésének oka lehet. Ito és mtsai. (2011) szintén a vakbél IgA szintjének emelkedéséről számoltak be patkányoknak adott $60 \mathrm{~g} / \mathrm{kg}$ inulin-kiegészítés során. Malactápok 4\%-os inulin-kiegészítése fokozták a duodenum mucin és mRNS termelését (Tako és $m$ tsai, 2008). Az ellentmondó eredmények egyik oka, hogy az immunválasz nagymértékben függ az adott élőlény korától és fajtájától, egyéb paramétereitől. A másik lehetséges ok, hogy a fekális IgA koncentráció nem a legjobb mérőszáma az immunrendszer működésének. Attól függően, hogy a prebiotikum 
a bélrendszer melyik szakaszában stimulálja a probiotikumok szaporodását, más-más eredményt kapunk az IgA koncentrációt illetően (Lomax és Calder, 2009).

\section{Az emésztőrendszer morfológiájában, az anyagcserében és a teljesít- ményben tapasztalt változások}

A The National Animal Health Monitoring Service szerint az amerikai állattartó telepek 57,5\%-a használt antibiotikum tartalmú tejpótlót 2007-ben (USDA, 2010). Ezek 49,5\%-ábanoxitetraciklin és neomicin kombinációját alkalmazták. Ugyanez a szám 2002-ben még csak 25,6\% volt. Az antibiotikumok kiváltására több lehetőség is van, mint pl. az állati eredetű szárított vérplazma, prebiotikumok, probiotikumok, aszkorbinsav és élesztősejtfal-alkotók (Kehoe és Carlson, 2015). A fiatal állatokat érintő bélrendszeri fertőzések komoly problémát jelentenek mind egészségügyi szempontból, mind pedig az üzem nyereségessége tekintetében. Ezen állatoknál az inulin és oligofruktóz a bélrendszerre gyakorolt kedvező hatása következtébenpozitívan befolyásolja az egyes termelési paramétereket.A bélsár konzisztencia javulása jól látható jele az emésztőrendszer egészségének, amire alapozva csökkenthető az antibiotikumok használata is. A prebiotikumok a mikrobiom összetételén keresztül képesek befolyásolni az emésztési folyamatokat. A keletkezett fermentációs termékek hatnak az anyagcserére, az állatok vérképére, immunrendszerére, az emésztőrendszer morfológiájára és persze mindezen keresztül a haszonállatok esetében a termelési mutatókra. Az inulin-kiegészítésnek köszönhető a nagyobb illózsírsav-koncentráció jótékony hatást gyakorol az anyagcserére, táplálja a bélsejteket, növeli az epithel sejtek számát a bélbolyhokban és növeli a bélbolyhok hosszát (Gibson és Roberfroid, 1995). Verdonk és mtsai. (2005) valamint VanLoo (2007) szerint sertésben az inulin-kiegészítés hatására a bélbolyhok meghosszabbodnak és ennek köszönhetően nő az abszorpciós kapacitás, ami a termelési eredmények javulásához vezet. Brambillasca és mtsai. (2015) ezzel szemben 3\% inulin-kiegészítés során nem találtak változást az emésztőkészülék morfológiájában és működésében, sőt, a kiegészítés lágyította a bélsarat és rontotta az állatok takarmányértékesítését, nitrogénretencióját. Metzler-Zebeli és mtsai. (2017) szintén a takarmányértékesítés romlásáról számoltak be malacok inulin-kiegészítése kapcsán. Broilercsirkék esetében Huang és mtsai. (2015) 5 g kiegészítés esetén a takarmányfelvétel növekedését tapasztalták, míg Verdonk és mtsai. (2005) a takarmányértékesítés és súlygyarapodás javulásáról, a tápcsatorna hosszának növekedéséről számoltak be. Broilerek esetén csökkent a vér koleszterinszintje és a zsír depozíció mértéke, 
míg tojótyúkok esetén javult a Ca-anyagforgalom és a tojástermelés(Verdonk és mtsai, 2005). Tejpótló tápszerek inulin-kiegészítésnek hatására az itatásos borjak testtömeg-gyarapodása javul, akárcsak a bélsár konzisztenciája (Kaufhold és mtsai 2000; Verdonk és Van Leeuwen, 2004). Azokban a vizsgálatokban, ahol a bélsár állagában nem tapasztaltak változást az inulin-kiegészít és javára, ott teljesítményjavulásról sem számoltak be (Masanetz és mtsai, 2010, 2011; Król 2011; Kara és mtsai, 2012). Ennek oka lehet az állatok és környezetük patogén terheltségének alacsony mértéke, az állatok jó egészségügyi állapota. Ettől függetlenül, az idézett szerzők vizsgálataiban is jelentkezett élettani hatás, amely azt bizonyítja, hogy az inulin akkor is hat a szervezetre, ha az teljesítményjavulásban nem mutatkozik. Król (2011) vizsgálataiban 3 és $6 \mathrm{~g} /$ nap inulin-kiegészítés hatására csökkent a karbamid- és koleszterinszint, és nőtt a vér hemoglobin- és fehérvérsejt-koncentrációja. A nagyobb hemoglobin-tartalmat és hematokrit értéket Masanetz és mtsai. (2011) a borjak jobb vasforgalmával magyarázzák, ami a teljes tejre alapozott borjúnevelésben kiemelkedő jelentőséggel bír.Vizsgálatukban beszámolnak a borjak trombocita és monocita koncentrációjának csökkenéséről. A sertésekben tapasztalt bélmorfológiát érintő változásokkal szemben Masanetz és mtsai. (2010) úgy találták, hogy itatásos borjak tejpótlójának 2\% inulin-kiegészítésekor csökken az ileumban a bélbolyhok hossza, a mucint termelő kehelysejtek és a proliferatív sejtek száma.

\section{KÖVETKEZTETÉSEK}

A felsorolt tudományos eredmények alapján elmondható, hogy az inulin, mint prebiotikus fruktán hatása a szervezet egészére mérhető. Az állat egészségi állapotát jelző pozitív változások nem minden esetben manifesztálódnak a teljesítmény növekedésében, de mindenképpen hozzájárulnak annak megfelelő és magas szinten tartásához. Az antibiotikumtól mentes, illetve annak csökkentését célul kitűző takarmányozási programok megfelelő alkotója lehet az inulin. A tudomány számára még sok lehetőséget kínál a különböző takarmányozási és tartási körülményeknek megfelelő optimális dózis, valamint a más takarmányalkotókkal való szinergens hatás feltérképezése.

\section{KÖSZÖNETNYILVÁNÍTÁS}

A publikáció elkészítését a EFOP-3.6.3-VEKOP-16-2017-00008 számú projekt támogatta. A projekt az Európai Unió támogatásával, az Európai Szociális Alap társfinanszírozásával valósult meg. 


\section{IRODALOM}

Adebola, O. O., Corcoran, O., Morgan, W. A. (2014). Synbiotics: the impact of potential prebiotics inulin, lactulose and lactobionic acid on the survival and growth of Lactobacilli probiotics. J. Funct. Foods, 10, 75-84. DOI: $10.1016 /$ j.jff.2014.05.010

Belval, H. (1927). Industrie de l'inuline et du le' vulose. In: Dix Ans d'Efforts Scientifiques, Industriels et Coloniaux 1914-1924. Chimie et Industrie, Paris, France, 1068-1069.

Brambillasca, S., Zunino, P., Cajarville, C. (2015). Addition of inulin, alfalfa and citrus pulp in diets for piglets: influence on nutritional and faecal parameters, intestinal organs, and colonic fermentation and bacterial populations. Livest. Sci., 178, 243-250. DOI: 10.1016/j.livsci.2015.06.003

Branner, G.R., Böhmer, B.M., Erhardt, W., Henke, J., Roth-Maier, D.A. (2004). Investigation on the precaecal and faecal digestibility of lactulose and inulin and their influence on nutrient digestibility and microbial characteristics. Arch. Anim. Nutr., 58(5), 353-366. DOI: $\underline{10.1080 / 00039420400005075}$

Bosscher, D., van Loo, J., Franck, A. (2006). Inulin and oligofructose as functional ingredients to improve bone mineralization. Int. Dairy J., 16(9), 1092-1097. DOI: 10.1016/j.idairyj.2005.10.028

Böhmer, B.M., Branner, G.R., Roth-Maier, D.A. (2005). Precaecal and faecal digestibility of inulin (DP 1012) or an inulin/Enterococcusfaecium mix and effects on nutrient digestibility and microbial gut flora. J. Anim. Physiol. Anim. Nutr., 89(11-12), 388-396. DOI: 10.1111/j.1439-0396.2005.00530.x

Casewell, M., Friis, C., Marco, E., McMullin, P., Phillips, I. (2003). The Europen ban on growth-promoting antibiotics and engineering consequences for humans and animal health. J. Antimicrob. Chemother., 52(2), 159-161. DOI: 10.1093/jac/dkg313

Gaggia, F., Mattarelli, P., Biavati, B. (2010). Probiotics and prebiotics in animal feeding for safe food production. Int. J. Food Microbiol., 141, S15-S28. DOI: 10.1016/j.ijfoodmicro.2010.02.031

Gibson, C. R., Roberfroid. M. B. (1995). Dietary modulation of human colonic microflora: introducing the concept of prebiotics. J. Nutr., 125(6), 1401-1412. DOI: 10.1093/jn/125.6.1401

Gibson, G. R., Roberfroid, M. B. (2008). Handbook of Prebiotics. CRC Press.

Halas, D., Hansen, C.F., Hampson, D.J., Mullan, B.P., Wilson, R.H.,Pluske, J. R. (2009). Effect of dietary supplementation with inulin and/or benzoic acid on the incidence and severity of post-weaning diarrhoea in weaner pigs after experimental challenge with enterotoxigenic Escherichia coli. Arch. Anim. Nutr., 63(4), 267-280. DOI: 10.1080/17450390903020414

Hall, M. B., Weimer, P. J. (2016). Divergent utilization patterns of grass fructan, inulin and other non fiber carbohydrates by ruminal microbes. J. Dairy Sci., 99(1), 245-257. DOI: 10.3168/jds.2015$\underline{10417}$

Hill, C., Guarner F.,Reid, G., Gibson, R. G., Merenstein, J. D., Pot, B., Morelli, L., Canani, R. B., Flint, H. J., Slminen, S., Calder, P. C., Sanders, M. E. (2014). The international scientific association for probiotics and prebiotics concensus statement on the scope and appropriate use of the term probiotic. Nat. Rev. Gastroenterol. Hepatol., 11(8), 506-514. DOI: 10.1038/nrgastro.2014.66

Huang, Q., Wei, Y., Wang, Y., Hu, T. (2015). Effect of dietary inulin supplements on growth performance and intestinal immunological parameters of broiler chickens. Livest. Sci., 180, 172-176. DOI: $\underline{10.1016 / j . l i v s c i .2015 .07 .015}$

Huebner, J., Wehling, R. L., Hutkins, R. W. (2007). Functionalactivity of commercial prebiotics. Int. Dairy J., 17(7), 770-775. DOI: 10.1016/j.idairyj.2006.10.006

Ito, H., Wada,T., Ohguchi, M., Sugiyama, K., Kiriyama, S., Morita, T. (2008). The degree of polymerization of inulin-like fructans affects cecal mucin and immunoglobulin A in rats. J. Food Sci., 73(3), H36H41. DOI: $10.1111 / j .1750-3841.2008 .00686 . x$ 
Ito, H., Takemura, N., Sonoyama, K., Kawagishi, H., Topping, D. L., Conlon, M. A., Morita, T. (2011). Degree of polymerization of inulin-type fructans differentially affects number of lacticacid bacteria, intestinal immune functions, and immunoglobulin A secretion in the rat cecum. J. Agric. Food Chem., 59(10), 5771-5778. DOI: 10.1021/if200859Z

Kara, C., Orman, A., Gencoglu, H., Kovanlikaya, A., Meral, Y., Cetin, I., Yibar A., Kasap S., Turkmen, I., Deniz, G. (2012). Effects of inulin supplementation on selected faecal characteristics and health of neonatal Saanen kids sucking milk from their dams. Animal, 6(12), 1947-1954. DOI: $10.1017 / s 1751731112000900$

Kaufhold, J., Hammon, H.M., Blum, J. W. (2000). Fructo-oligosaccharide supplementation: effects on metabolic, endocrine and hematological traits in veal calves. J. Vet. Med. Ser. A, 47(1), 17-29. DOI: $\underline{10.1046 / j .1439-0442.2000 .00257 . x}$

Kehoe, S. I., Carlson, D. B. (2015). Influence of nonmedicated additives as alternatives to antibiotics on calves growth and health. Prof. Anim. Sci., 31(6), 516-522. DOI: 10.15232/pas.2015-01416

Król, B. (2011). Effect of mannanoligosaccharides, inulin and yeast nucleotides added to calf milkreplacers on rumen microflora, level of serum immune globulin and healthcondition of calves. Electron. J. Pol. Agric. Univ. 2.14.

Lomax, A. R., Calder, P. C. (2009). Prebiotics, immune function, infection and inflammation: A review of the evidence. Br. J. Nutr., 101(5), 633-658. DOI: 10.1017/s0007114508055608

Loveren H.,Sanz Y., Salminen, S. (2012). Health claims in Europe: probiotics and prebiotics as case examples. Annu. Rev. Food Sci. Technol., 3(1), 247-261. DOI: 10.1146/annurev-food-022811-101206

Masanetz, S., Wimmer, N., Plitzner, C., Limbeck, E., Preißinger, W., Pfaffl, M. W. (2010). Effects of inulin and lactulose on the intestinal morphology of calves. Animal, 4(5), 739-744. DOI: $\underline{10.1017 / s 1751731109991728}$

Masanetz, S., Preißinger, W., Meyer, H. H. D., Pfaffl, M. W. (2011). Effects of the prebiotics inulin and lactulose on intestinal immunology and hematology of preruminant calves. Animal, 5(7), 10991106. DOI: $10.1017 / s 1751731110002521$

McKellar, R. C., Modler, H. W., Mullin, J. (1993). Characterization of growth and inulinase production by Bifidobacterium spp. on Fructooligosaccharides. Bifidobacteria and Microflora, 12(2), 75-86. DOI: $\underline{10.12938 / \text { bifidus1982.12.2 } 75}$

Metzler-Zebeli, B. U., Trevisi, P., Prates, J. A. M., Tanghe, S., Bosi, P., Canibe, N., Montagne, L., Freire, J., Zebeli, Q. (2017). Assessing the effect of dietary inulin supplementation on gastrointestinal fermentation, digestibility and growth in pig: A meta-analysis. Anim. Feed. Sci. Tech., 233, 120-132. DOI: $\underline{10.1016 / j \text {.anifeedsci.2017.05.010 }}$

Niness, K. R. (1999). Inulin and oligofructose: What are they? J. Nutr., 129(7), 1402S-1406S. DOI: 10.1093/jn/129.7.1402s

Parker, R. B. (1974). Probiotics, the other half of the antibiotic story. Anim. Nutr. Health, 29, 4-8.

Perlmutter, D. (2017). Agyépítők: Hogyan gyógyítja és védi agyunkat az egészséges bélflóra-egy életen át. Kossuth Kiadó, Budapest

Samanta, A. K., Jayapal, N., Senani, S., Kolte, A. P., Sridhar, M. (2013). Prebiotic inulin: useful dietary adjuncts to manipulate the livestock gut microflora. Braz. J. Microbiol., 44(1), 1-14. DOI: $10.1590 / s 1517-83822013005000023$

SooBo, S. (2005). Effects of prebiotics, probiotics and synbiotics in the diet of young pigs [dissertation]. Wageningen University, Wageningen, Netherlands.

Tako, E., Glahn, R.P., Welch, R.M., Lei,X., Yasuda, K., Miller, D.D. (2008). Dietary inulin affects the expression of intestinal enterocyte iron transporters, receptors and storage protein and alters the microbiota in the pig intestine. Br. J. Nutr., 99(3), 472-480. DOI: $\underline{10.1017 / s 0007114507825128}$ 
USDA (2010). HeiferCalf Health and Management Practices on US Dairy Operations, 2007. USDA: Animal and Plant Health Inspection Service: Vet. Serv., Center Epidemiol. Anim. Health, Fort Collins, USA.

Van Loo, J., Bosscher, D., Janssens, G. P. (2006). Prebiotic inulin interacts with the caecal fermentation in the horse. Horse health nutrition: Third European Equine Health and Nutrition Congress, Faculty of Veterinary Medicine of Ghent University, Merelbeke, Belgium, 75-82.

Van Loo, J. (2007). How chicory fructans contribute to zootechnical performance and well-being in livestock and companion animals. J. Nutr., 137(11 Suppl), 2594S-2597S. DOI: 10.1093/jn/137.11.2594s

Verdonk, J.M.A.J., Shim, S.B., van Leeuwen, P., Verstegen, M.W. A. (2005). Application of inulin-type fructans in animal feed and pet food. Br. J. Nutr., 93(S1), S125-S138. DOI: $10.1079 /$ bjn20041355

Verdonk, J. M. A. J., van Leeuwen, P. (2004). The application of inulin-type fructans in diets for veal calves and broilers. Ininulin and oligofructose feel good factors for health and well-being. 4th Orafti ResearchConference, Paris, 50-51.

Verstegen, M.W.A., Williams, B.A. (2002). Alternatives to the use of antibiotics as growthpromoters for monogastric animals. Anim. Biotechnol., 13(1), 113-127. DOI: 10.1081/abio-120005774

Vogt, L., Meyer, D., Pullens, G., Faas, M., Smelt, M. (2015). Immunological properties of inulintypefructans. Crit. Rev. Food Sci. Nutr., 55(3), 414-436. DOI: 10.1080/10408398.2012.656772 